\title{
Determination of Changes of Amylose and Amylopectin Content of Paddy during Early Storage
}

\author{
Achala Abeysundara ${ }^{1}$, Seneviratne Navaratne ${ }^{2}$, Indira Wickramasinghe ${ }^{3}$, Dinindu Ekanayake ${ }^{4}$ \\ Department of Food Science \& Technology, Faculty of Applied Sciences \\ University Sri Jayewardenepura, Gangodawila, Nugegoda, Sri Lanka
}

\begin{abstract}
Rice (Oryza sativa L.) is the most important cereal crop in Sri Lanka since it is the staple food. Paddy is stored for a considerable period of time before consumption. Amylose and amylopectin contents of rice are very important parameters in determining eating quality of rice. Freshly harvested paddies of three rice varieties BG 300, BG 352 and AT 362 were obtained. Cleaned and dried paddy samples were stored at ambient temperature conditions. Amylose content of each rice variety was determined in every two weeks period during four months storage using simplified assay technique. During 13 weeks storage there is no significant variation in amylose content. But slight decreasing trend was observed in each variety. 40 weeks old paddy samples of same rice varieties obtained from same fields showed a significant reduction in amylose content during storage $(p<0.05)$.
\end{abstract}

Keywords: Sri Lankan rice varieties, Amylose/Amylopectin content, Early storage

\section{Introduction}

Rice is the single most important crop and it is cultivated $34 \%$ area in total cultivated lands in Sri Lanka. Around 870 000 ha of lands are cultivated rice in both cultivating seasons the Yala and Maha. Around 1.8 million families are engaged in rice production and annually 2.7 million tons of rough rice is produced in Sri Lanka. Majority of Sri Lankans fulfill their protein and calorie requirement through consumption of rice. Per capita consumption of rice is around $100 \mathrm{~kg}$ in Sri Lanka [1].

Rice is divided into three main sub-species. They are Indica which is grown in tropical regions (made of slender and somewhat flat grains), Japonia grown in temperate regions (short, round and smaller grains) and Javanica cultivated mainly in Indonesia (broad thick grains). Rice grown in Sri Lanka belongs to the sub species of Indica [2].

Rice is a rich source of starch. Eating \& cooking quality of starch totally depends on the starch content of rice. Predominant component present in endosperm or inner part of the rice kernel is carbohydrate. It consists of $85-90 \%$ of starch, $2 \%$ pentose and $1 \%$ sugars. The starch fraction is made out of amylose and amylopectin. Sensory and cooking quality of the rice totally depends on amylose and amylopectin fraction of rice kernel [3], [4].

The amylose content of widely grown rice varieties in Sri Lanka is in between $25-30 \%$ where the cooked rice is nonsticky \& hard. Rice varieties with amylose content below $6 \%$ remain sticky following cooking [3], [2]. Protein is the second most abundant component in rice and its quality is high compared to other protein sources. The average protein content is $7 \%$ in milled rice and $8 \%$ in brown rice [4].

Consumer preference for rice mainly depends on final texture of cooked rice. Different rice varieties have different unique texture following cooking. Since starch is the main constituent in rice, it governs the final texture of cooked rice. Starch characteristics determine the amylose content and gelatinization temperature [5], [6]. Amylose and amylopectin determines the cooking quality of rice. Sri Lankans mostly prefer non sticky rice varieties which have higher amylose content in between 25\%-30\% [2].

Textural properties of rice are crucial sensory parameter in determining eating quality of cooked rice. Hardness and stickiness are the most important parameters in determining texture and eating quality of rice [7]. Texture of cooked rice depends on several parameters such as amylose content, post-harvest processing and cooking method. Among them amylose content is the most crucial parameter in determining final texture of cooked rice. Ramesh et al 1990 proposed that texture depends on the amylopectin structure as well. He further stated that short and long chain amylopectin chains play crucial role for the final texture of cooked rice [8].

Aging initiated before harvest and it continues as a time, temperature and moisture dependent process. Comprehensive knowledge on aging is beneficial in determining cooking and eating quality of rice [9]. Aging results in various physical and chemical changes that lead to have high head rice yield on milling, high water absorption and expansion on cooking and harder less sticky texture upon cooking. The changes include flavor, color, compositional variations. Effects of aging are more prominent in stored non-waxy rice (high amylose) compared to waxy rice [10]. Juliano (1981) stated that minimum three month period is required to observe chemical and physical changes occur due to aging process [11].

\section{Materials \& Methods}

\section{Sample collection}

Ten kilo grams of commercially available, three prominent improved paddy varieties were selected for the study (BG 300, BG 352 and AT 362). [BG- Bathalegoda ; ATAmbalangoda - The letters depicted two Paddy research centers in Sri Lanka] Freshly harvested BG-352 rice variety was obtained from commercial paddy farmers in Buttala area in Moneragla district. AT-362 rice variety was taken from the Ambalantota rice research center in Hambantota district. BG-300 rice variety was obtained from Labuduwa 


\section{International Journal of Science and Research (IJSR) \\ ISSN (Online): 2319-7064 \\ Index Copernicus Value (2015): 78.96 | Impact Factor (2015): 6.391}

rice research center in Galle district. 10 months old paddy samples of same varieties were obtained from same institutes.

\section{Sample storage}

All paddy samples were cleaned and all the impurities such as stones, broken husks, parts of hay were removed and all paddy samples were sun dried under shade conditions for three days. Then samples were stored in plastic baskets in house conditions (RH-70-80\%, Temperature-26-30 ${ }^{\circ} \mathrm{C}$ ). Samples were dried and mixed in every two weeks under sundry conditions.

\section{Flour preparation}

The paddy samples were dehusked using small wooden mortar and pestle. After dehsuking rice grains were ground using a blender at medium speed. Mortar and pestle as well as the blender parts were thoroughly cleaned in order to avoid mixing of varieties. Rice flour was sieved using 100 mesh sieve. Sieved flour was stored in air tight containers until it is analyzed.

\section{Determination Amylose content (AC)}

Initially $40.00 \mathrm{mg}$ of pure potato amylose was weighed into a beaker. Then $1 \mathrm{ml}$ of $95 \%$ ethanol and $9 \mathrm{ml}$ of $1 \mathrm{~N} \mathrm{NaOH}$ was added and the mixture was heated in a boiling water bath for 15 minutes. Then the solution was allowed to cool to room temperature and it was transferred to a $100 \mathrm{ml}$ volumetric flask. The solution was topped up with distil water. Then $1 \mathrm{ml}, 2 \mathrm{ml}, 3 \mathrm{ml}, 4 \mathrm{ml} \& 5 \mathrm{ml}$ of aforementioned solution was transferred to $100 \mathrm{ml}$ volumetric flasks covered with aluminium foils. Then a series of standard solutions were prepared by adding $0.2 \mathrm{ml}, 0.4 \mathrm{ml}, 0.6 \mathrm{ml}, 0.8 \mathrm{ml}$ and $1 \mathrm{ml}$ of $1 \mathrm{~N}$ Acetic acid solution respectively. Afterwards $2 \mathrm{ml}$ of $0.2 \%$ Iodine solution was added to all flasks and shaken. Then all the prepared solutions were kept in a dark box for 20 minutes and absorbance was measured using UV-VIS spectrophotometer. Standard curve was drawn against the absorbance and amylose concentration. To prepare the blank solution $5 \mathrm{ml}$ of $0.09 \mathrm{~N} \mathrm{NaOH}$ solution was added to $100 \mathrm{ml}$ volumetric flask. Then $1 \mathrm{ml}$ of $1 \mathrm{~N}$ acetic acid \& Iodine solution were added and kept in dark for 20 minutes before measuring absorbance (SHIMADZU UVmini-1240). The same procedure was carried out for the sample using $100 \mathrm{mg}$ of rice flour instead of standard amylose. But $5 \mathrm{ml}$ of starch solution was reacted with $1 \mathrm{ml}$ of $1 \mathrm{~N}$ acetic and $2 \mathrm{ml}$ of $0.2 \%$ iodine instead of preparing a series of solutions. Absorbance was measured at $620 \mathrm{~nm}$. The amylose percentage of sample was determined as described by Juliano, 1971 [12], [13].

\section{Determination of Amylopectin content (AP)}

Amylopectin content was calculated using the following equation explained by Torruco-Uco et al (2006). The average amylose content value was taken for the calculation [14].

\section{Amylopectin $\quad=(100-$ Amylose \% $)$}

Amylose content and amylopectin content of three rice varieties were measured in every two weeks for a period of 14 weeks to determine the variations. Also amylose contents of 40 weeks old samples of same varieties were analyzed.

\section{Data analysis}

One way ANOVA tests were carried out for amylose contents values to determine whether there is a significant variation of amylose content during storage. ( $\mathrm{CI}=95 \%)$. Minitab 17 software was used for statistical analysis.

\section{Results \& Discussion}

Table 1: Amylose content of paddy during storage

\begin{tabular}{|c|c|c|c|}
\hline Week/Time & BG 352(AC \%) & AT 362(AC \%) & BG 300(AC \%) \\
\hline 1 & $26.43 \pm 0.03^{\mathrm{a}}$ & $26.66 \pm 0.08^{\mathrm{a}}$ & $25.22 \pm 0.08^{\mathrm{ab}}$ \\
3 & $26.45 \pm 0.07^{\mathrm{a}}$ & $26.89 \pm 0.09^{\mathrm{a}}$ & $25.26 \pm 0.06^{\mathrm{ab}}$ \\
5 & $26.32 \pm 0.04^{\mathrm{ab}}$ & $26.72 \pm 0.10^{\mathrm{a}}$ & $25.42 \pm 0.09^{\mathrm{a}}$ \\
7 & $26.32 \pm 0.04^{\mathrm{ab}}$ & $26.62 \pm 0.01^{\mathrm{a}}$ & $25.18 \pm 0.06^{\mathrm{ab}}$ \\
9 & $26.43 \pm 0.07^{\mathrm{a}}$ & $26.63 \pm 0.10^{\mathrm{a}}$ & $25.17 \pm 0.09^{\mathrm{b}}$ \\
11 & $26.22 \pm 0.06^{\mathrm{b}}$ & $26.70 \pm 0.06^{\mathrm{a}}$ & $25.15 \pm 0.04^{\mathrm{b}}$ \\
13 & $26.24 \pm 0.07^{\mathrm{b}}$ & $26.83 \pm 0.01^{\mathrm{a}}$ & $25.18 \pm 0.03^{\mathrm{ab}}$ \\
Old/40 & $24.59 \pm 0.09^{\mathrm{c}}$ & $25.10 \pm 0.15^{\mathrm{b}}$ & $24.72 \pm 0.16^{\mathrm{c}}$ \\
\hline
\end{tabular}

Values that do not share a letter are significantly different (within columns).

Table 2: Amylopectin content of paddy during storage \begin{tabular}{|l|l|l|l|}
\hline Week/Time & BG 352(AP \%) & AT 362(AP \%) & BG 300(AP \%) \\
\hline
\end{tabular}

\begin{tabular}{|c|c|c|c|}
\hline 1 & $73.57 \pm 0.03$ & $73.33 \pm 0.08$ & $74.78 \pm 0.06$ \\
3 & $73.55 \pm 0.07$ & $73.11 \pm 0.10$ & $74.74 \pm 0.07$ \\
5 & $73.67 \pm 0.04$ & $73.28 \pm 0.10$ & $74.58 \pm 0.09$ \\
7 & $73.68 \pm 0.05$ & $73.38 \pm 0.10$ & $74.82 \pm 0.06$ \\
9 & $73.57 \pm 0.07$ & $73.36 \pm 0.10$ & $74.82 \pm 0.09$ \\
11 & $73.78 \pm 0.06$ & $73.30 \pm 0.06$ & $74.85 \pm 0.04$ \\
13 & $73.76 \pm 0.07$ & $73.17 \pm 0.09$ & $74.81 \pm 0.03$ \\
Old $/ 40$ & $75.41 \pm 0.09$ & $74.90 \pm 0.15$ & $75.28 \pm 0.15$ \\
\hline
\end{tabular}

Values that do not share a letter are significantly different (within columns).

Amylose and Amylopectin content of BG 352, BG 300 and AT 362 rice varieties are given in table 1 \& table 2 . According to table 1 statistically, there is no significant variation in amylose content during 13 weeks period of storage. But the values clearly indicate that amylose contents of all paddy varieties are gradually declining throughout the early storage period. In order to validate this outcome, amylose contents of same paddy varieties at 40 weeks storage were analyzed. Further the data obtained from the study were analyzed statistically and found that there was a significant different between declining of amylose content and age of the paddy variety $(\mathrm{P}<0.05)$. Hence it is evident that amylose content of all three rice varieties reduces during storage. The reduction of amylose contents of BG 300, BG 352 and AT 362 are $0.5 \%, 1.64 \% \& 1.72 \%$ respectively during 40 weeks storage period.

The data given in table 1 indicates that amylose content is gradually declined, but rate of which is scant. Since fresh paddy grains are having considerable amount of simple sugars and germ of it still in maturing stage, simple sugar is the energy source for day to day metabolic activity. However with the aging process the germ would be stabilized, while exhausting simple form of carbohydrate. Hence grain compelled to metabolize starch in simple form particularly amylose. Hence declining of amylose at the early stage period of storage is very slight and thereafter degradation pattern is relatively rapid. The reason for this consequence is utilizing of amylose in the germ for the metabolic activity during storage period. 


\section{International Journal of Science and Research (IJSR) \\ ISSN (Online): 2319-7064}

Index Copernicus Value (2015): 78.96 | Impact Factor (2015): 6.391

Rice can be classified into several groups based on amylose content rice can be categorized as waxy $(1-2 \%)$, very low amylose content $(2-12 \%)$, low amylose content (12-20\%), intermediate amylose content $(20-25 \%)$ and high amylose (25-33\%) [1], [15]. According to above classification all the rice varieties can be classified under high amylose rice. The amylose content of $\mathrm{BG} 352, \mathrm{BG} 300$ and $\mathrm{AT} 362$ rice varieties range from $26.22 \pm 0.06-26.45 \pm 0.07,25.15 \pm 0.04$ $25.42 \pm 0.09$ and 26.62 $\pm 0.01-26.89 \pm 0.09$ respectively. According to above amylose content, the texture of cooked rice of above varieties should be less sticky and harder. Previous studies of amylose content suggests that high amylose rice varieties yields a harder and less sticky rice upon cooking and hardness is positively correlated with the amylose content of rice [8]. However, freshly harvested rice tends to be sticky.

According to Juliano the variations occur due to aging process become visible at least 3-4 months after harvesting at $15^{\circ} \mathrm{C}$ [8], [11]. Therefore, this result is in line with the studies done by Juliano. Storage temperature is critical during aging. At elevated temperatures the changes are more rapid in rice varieties [16], [7]. Patindol stated that at high temperatures amylose content of rice decreased significantly after 7 to 9 months. The storage temperature used in this study was about $25^{\circ} \mathrm{C}-30^{\circ} \mathrm{C}$. Hence significant reduction is not observed during early storage.

It has been reported that amylolytic enzymes remain active during rough rice storage although their activity tends to decrease over time. Inner parts of the endosperms have higher temperature, which is ideal for enzymatic activity of amylase and other hydrolytic enzymes. Therefore amylose content reduces during storage. Amylose is more susceptible to enzyme attack whilst amylopectin remains resistant compared to amylose. This variation occurs as the amylose molecules are generally confined in the amorphous layers of the starch granules which are more susceptible to enzymatic attack and other chemical changes than the amylopectin-rich crystalline layers [7].

According to previous research studies, available amylose content should yield hard, non-sticky rice just after harvesting, if amylose is the major factor that governs the texture of cooked rice. But according to above information the depletion of amylose in BG 352, BG 300 \& AT 362 is $1.64 \%, 0.5 \%$ \& $1.72 \%$ respectively after 40 weeks storage. Therefore it cannot be concluded that amylose is the major factor which governs the texture of rice during aging.

\section{Conclusion}

Amylose contents of BG 300, BG 352 and AT 362 rice varieties do not show significant reduction of amylose content during 13 weeks storage. However, amylose contents of all rice samples are reducing during long period of storage. During early storage rice grains utilize simple sugars for metabolism. Consequently there is no significant reduction in amylose content during early storage.

\section{Acknowledgement}

Authors specially thank for the guidance and support provided by the Institute of Post-Harvest Technology (Research and Development Centre), Anuradhapura, Sri Lanka.

\section{References}

[1] Abeysekara WKSM, Somasiri HPPS, Premakumara GAS, Bentota AP, Rajapaksha D, Ediraweera N. Cooking \& Eating Quality Traits of Some Sri Lankan Traditional Rice Varieties across Yala \& Maha Seasons. Tropical Agriculture Research. 2008;20:168-76.

[2] Samaraweera U. Nutritional Quality of Rice. Economic Review January- March 1999. 1999:17-20.

[3] Asghar S, Anjum FMA, Amir RM, Khan MA. Cooking and eating characteristics of Rice (Oryza sativa L.)-A. Pakistan Journal of Food Sciences. 2012;22(3):128-32.

[4] Oko A, Ubi BE, Efisue AA, Dambaba N. Comparative analysis of the chemical nutrient composition of selected local and newly introduced rice varieties grown in Ebonyi state of Nigeria. International Journal of Agriculture and Forestry. 2012 Apr 9;2(2):16-23.

[5] Allahgholipour M, Ali AJ, Alinia F, Nagamine T, Kojima Y. Relationship between rice grain amylose and pasting properties for breeding better quality rice varieties. Plant Breeding. 2006 Aug;125(4):357-62.

[6] Odenigbo AM. Study on the Gelatinization properties and Amylose content of rice varieties from Nigeria and Cameroun. International Journal of Nutrition and Food Sciences. 2013;2(4):181.

[7] Patindol J, Wang Y-J, Jane J. Structure-Functionality changes in starch following rough rice storage. Starch Stärke. 2005 May;57(5):197-207.

[8] Li H, Prakash S, Nicholson TM, Fitzgerald MA, Gilbert RG. The importance of amylose and amylopectin fine structure for textural properties of cooked rice grains. Food Chemistry. 2016 Apr;196:702-11.

[9] Zhou Z, Robards K, Helliwell S, Blanchard C. Ageing of stored rice: Changes in chemical and physical attributes. Journal of Cereal Science. 2002 Jan;35(1):65-78.

[10] Keawpeng I, Venkatachalam K. Effect of aging on changes in rice physical qualities. International Food Research Journal. 2015;22(6):2180-7.

[11] Villareal RM, Resurreccion AP, Suzuki LB, Juliano BO. Changes in Physicochemical Properties of Rice during Storage. Starch. 1976;28(3):88-94.

[12] Juliano BO. A Simplified Assay for Milled-Rice Amylose. Cereal Science Today. 1971;16:334-8.

[13] Perez CM, Juliano BO. Modification of the simplified Amylose test for milled rice. Starch - Stärke. 1978;30(12):424-6.

[14] Torruco-Uco JG, Chel-Guerrero LA, Betancur-Ancona D. Isolation and molecular characterization of Makal (Xanthosoma yucatanensis) starch. Starch - Stärke. 2006 Jun;58(6):300-7.

[15] Thumrongchote D, Suzuki T, Laohasongkram1, K, Chaiwanichsiri S. Properties of Non-glutinous Thai Rice Flour: Effect of rice variety. Research Journal of Pharmaceutical, Biological and Chemical Sciences. 2012;3(1):150-64.

\section{Volume 6 Issue 1, January 2017}




\section{International Journal of Science and Research (IJSR) \\ ISSN (Online): 2319-7064}

Index Copernicus Value (2015): 78.96 | Impact Factor (2015): 6.391

[16] McDonough CM, Floyd CD, Waniska RD, Rooney LW. Effect of accelerated aging on maize, sorghum, and sorghum meal. Journal of Cereal Science. 2004 May;39(3):351-61.

[17] Kongseree N, Juliano BO. Physicochemical properties of rice grain and starch from lines differing in amylose content and gelatinization temperature. Journal of Agricultural and Food Chemistry. 1972 May;20(3):7148 . 